Joyful Learning Journal

\title{
KEEFEKTIFAN MODEL MIND MAPPING BERBANTUAN MEDIA DISPLAY TERHADAP HASIL BELAJAR IPS
}

\author{
Rafika Damayanti $^{\bowtie}$, Purnomo
}

Jurusan Pendidikan Guru Sekolah Dasar, Fakultas Ilmu Pendidikan, Universitas Negeri Semarang, Indonesia

\begin{tabular}{|c|c|}
\hline Info Artikel & Abstrak \\
\hline Sejarah Artikel: & $\begin{array}{l}\text { juan penelitian ini adalah untuk menguji keefektifan model Pembelajaran Mind Mapping berbantuan Media } \\
\text { isplay terhadap hasil belajar siswa kelas IV SD N Gugus KH.Samanhudi Kendal.Penelitian ini menggunakan }\end{array}$ \\
\hline & etode Kuantitatif dan jenis penelitian quasi eksperimen. Sampel dalam penelitian ini adalah kelas IV SD N \\
\hline Diset! & 28 siswa.Data \\
\hline Dipublika & eksperimen. Hasil perhitungan menggunakan Independent Sam \\
\hline 2020 & $\begin{array}{l}\text { arena hasil penelitian menunjukan bahwa kolom (2- tailed) yaitu sebesar } 0,000 \text { yang berarti lebih kecil dari } 0.05 \text {. } \\
\text { impulannya bahwa model pembelajaran Mind Mapping berbantuan media display efektif digunakan dalam }\end{array}$ \\
\hline & $\begin{array}{l}\text { rbantuan media display dalam pembelajaran di kelas dan untuk model mencatat sehari-hari agar dapat } \\
\text { eningkatkan hasil belajar siswa sehingga mutu sekolah dapat meningkat. }\end{array}$ \\
\hline
\end{tabular}

social studies; effectivenes,

mind maaping

\section{Abstract}

\begin{abstract}
The purpose of this study was to test the effectiveness of the Mind Mapping Learning Model assisted by Display Media in the fourth grade students' learning outcomes at KH. Samanhudi Cluster Elementary School, Kendal Regency. This study used a quantitative method and quasi-experimental type of research. The samples in this study were the fourth grade students at Sendangdawuhan 02 Elementary School in the number of 26 students as the experimental class, the fourth grade students at Bulak 02 Elementary School in the number of 28 students. The learning outcomes were analyzed using t-test to test the average difference of the control class and the experimental class. The result of calculations using the Independent Sample T-Test addressed if the value (2-tailed) $<0.05$, because the results of the study showed that the column (2-tailed) was equal to 0,000 which means it was smaller than 0.05. The conclusion was the Mind Mapping learning model assisted by display media was effectively used in social studies learning. It was suggested for the teachers and the students to apply Mind Mapping learning model assisted by display media in the classroom and for note-writing in order to improve students' learning outcomes so that the school quality could also improve.
\end{abstract}

(C) 2020 Universitas Negeri Semarang

Desa Purbowangi,Bawang RT 04 RW 06 Kec. Buayan.Kebumen

E-mail: damayantirafika93@gmail.com

ISSN 2252-6366 


\section{PENDAHULUAN}

Pendidikan merupakan sistem dengan menampilkan fakta bahwa susunan rencana, penerapan, dan pembinaan dan bimbingan pendidikan sangatlah kompleks dan melibatkan banyak faktor di dalamnya. UU Republik Indoneisa Nomor 20 Tahun 2003 mengenai sistem pendidikan nasional pasal 37 ayat 1 yang menjabarkan bahwa kurikulum pendidikan dasar dan menengah diharuskan untuk mempelajari 1) Pendidikan Agama, 2) PKn, 3) Bahasa, 4) Matematika, 5) Ilmu Pengetahuan Alam, 6) Ilmu Pengetahuan Sosial,7) Seni Budaya,Pendidikan jasmani dan Olahraga, 8) Keterampilan atau kejuruan dan 9) Muatan Lokal. Seuai dengan Peraturan Pemerintahan Mentri Pendidikan dan Kebudayaan Nomor 21 tahun 2016 yang menjelaskan mengenai Standar Isi pendidikan utuk jenjang Pendidikan Dasar dan Menengah bahwa di dalam sistem Kurikulum SD/MI memuat 8 pelajaran, dan yang salah satunya yaitu mata pelajaran Ilmu Pengetahuan Sosial.

Salah satu mata pelajaran yang menunjukkan hasil belajar rendah adalah mata pelajaran Ilmu Pengetahuan Sosial (IPS). IPS adalah sebuah program pendidikan dan bukan sub-disiplin ilmu tersendiri, sehingga tidak akan ditemukan baik dalam nomenklatur filsafat ilmu, disiplin ilmu-ilmu sosial (social sciences), maupun ilmu pendidikan (Somantri, 2001).Dewasa ini, timbul beberapa permasalahan terkait dengan pembelajaran IPS di Sekolah Dasar. Permasalahan utama yang sering terjadi pada pembelajaran IPS adalah terkait dengan standar proses. Permasalahan tersebut diantaranya strategi pembelajaran yang masih satu arah, penilaian yang berbasis kelas yang kurang variatif, dan sarana pembelajaran yang masih minim seperti tidak adanya media yang digunakan, serta kualifikasi guru yang masih rendah.

Sesuai dengan Peraturan Menteri Pendidikan dan Kebudayaan Republik Indonesia No. 65 tahun 2013 bab V tentang penilaian hasil dan proses pembelajaran menyatakan bahwa penilaian proses pembelajaran menggunakan pendekatan penilaian otentik (authentic assesment) yang menilai kesiapan siswa, proses, dan hasil belajar secara utuh. Keterpaduan penilaian ketiga komponen tersebut akan menggambarkan kapasitas, gaya, dan perolehan belajar siswa atau bahkan mampu menghasilkan dampak instruksional (instructional effect) dan dampak pengiring (nurturant effect) dari pembelajaran. Namun, di SD Gugus KH. Samanhudi Kendala nilai evaluasi mata pelajaran IPS hanya diukur berdasarkan ranah kognitif.

Berlandaskan permasalahan yang telah dikemukakan pernyataan sebelumnya, mengenai permasalahan pada pembelajaran IPS juga timbul di lingkup SD,sesuai dengan kegiatan pra penelitian yang dilaksanakan melalui proses observasi, wawancara, dan data dokumen berupa hasil belajar di SDN Gugus KH. Samanhudi Kendal kelas IV didapati beberapa permasalahan dalam proses pembelajaran. Minimnya ketertarikan peserta didik pada pembelajaran ini dikarenakan terdapat faktor yaitu Materi IPS yang terlalu banyak menghafal, kurangnya media sebagai alat pembelajaran yang digunakan, dan juga Model yang dipilih oleh pengajar kurang sesuai dengan materi yang ada. Model pembelajaran yang diterapkan di SD tersebut menggunakan model Direct Intruction, namun pembelajaran dengan menggunakan model tersebut dirasa belum optimal karena tidak sesuai dengan prinsip dari Kurikulum 2013 dimana pada model ini pengajar masih menjadi center atau masih memiliki peran yang banyak, dengan hal ini peserta didik kurang terdorong utuk meningkatkan rasa tanggung jawab,dan cenderung untuk pasif,

Data kualitatif tersebut didukung dengan data hasil belajar UTS IPS kelas IV SDN Gugus KH.Samanudi Tahun Ajaran 2019/2020 dari jumlah siswa sebanyak 138 siswa, 70 siswa $(50,72 \%)$ hasil belajar IPS masih di bawah KKM dan sisanya 68 siswa $(49,27 \%)$ sudah di atas KKM yaitu 70. Djamarah (2013: 108) menyatakan jika pembelajaran bisa dinyatakan berhasil apabila mencapai $75 \%$ atau lebih dari jumlah peserta didik yang mengikuti proses kegiatan pembelajaran mencapai taraf keberhasilan, dan apabila masih belum mencapai batas tersebut maka langkah yang harus diambil yaitu melakukan program perbaikan atau remidial.

Berdasarkan permasalahan mengenai pembelajaran IPS tersebut peneliti ingin menguji Keefektifan Model Pembelajaran berbantuan media belajar. Model yang dipilih untuk penelitian kali ini yakni Model Pembelajaran Mind Mapping berbantuan media Display. Dengan menggunakan Model Pembelajaran Mind Mapping atau yang umum dapat disebut dengan peta pikiran dan berbantu Media Display diharapkan peserta didik dapat mengikuti kegiatan belajar dikelas dengan lebih efektif.

Topik permasalahan yang hampir memiliki kesamaan dengan penelitian kali ini antara lain penelitian yang dilakukan oleh Catur Adiguna, dkk (2014), yaitu menunjukan perbedaan yang cukup tinggi antara pembelajaran accelerate learning mind mapping dengan konvensional, terbukti dengan hasil t hitung lebih dari ttabel yaitu 2,13>2,00 dengan perolehan rata-rata nilai hasil belajar IPA kelas eksperimen lebih tinggi dari kelas kontrol yaitu 79,33 > 72,71.

Jurnal penelitian internasional oleh $\mathrm{S} O$ Adodo Ph.D. (Vol. 4 No. 6 tahun 2013) Hasil penelitian menbutkan bahwa, strategi Mind Mapping sebagai Self-Regulated Learning (SRL), membantu untuk meningkatkan kinerja siswa dalam BST dan harus digunakan di kelas sebagai pendekatan yang baik untuk mengajar Basic 
Science dan Technology (BST), selanjutnya Penelitian Ying Liu, dkk (Volume 2 No 1 tahun 2014), dalam penelitiannya disimpulkan bahwa meta-analysis menunjukkan bahwa Mind Mapping mempunyai pengaruh positif dalam kegiatan pembelajaran yang dapat memberikan pengaruh terhadap hasil dan prestasi belajar.

Berdasarkan uraian latar belakang tersebut, maka peneliti akan menkaji melalui penelitian eksperimen dengan judul "Keefektifan Model Pembelajaran Mind Mapping Berbantuan Media Display terhadap Hasil Belajar IPS Kelas IV SDN Gugus KH. Samanhudi Kendal”.

\section{METODE PENELITIAN}

Jenis penelitian ini adalah penelitian eksperimen yang mengarah pada hubungan sebab akibat kepada dua variabel atau lebih dengan treatment. Desain penelitian Eksperimen diantaranya meliputi : Pre Experimental design, The Experimental Design, Factorial Design, Quasi Experimental design (Sugiyono 2015:108).

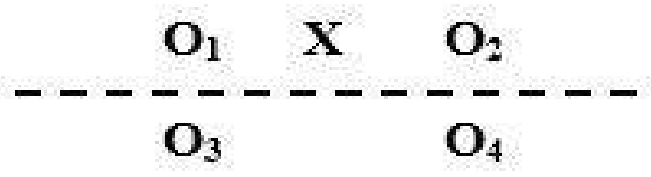

Gambar 1. Desain Penelitian Nonequivalent Control Group Design

Populasi yang diambil dalam penelitian mencakup semua siswa kelas 4 SD N Gugus KH. Samanhudi Kabupaten Kendal yang terdiri dari 6 sekolah,yaitu sebagai berikut:

Tabel 1 Data Siswa SD N Gugus KH. Samanhudi

\begin{tabular}{ccc}
\hline No & Nama Sekolah & Jml Siswa Kls 4 \\
\hline 1 & SDN Sendangdawuhan 01 & 22 \\
2 & SDN Sendangdawuhan 02 & 26 \\
3 & SDN Bulak 01 & 19 \\
4 & SDN Bulak 02 & 28 \\
5 & SDN Kebonsari 01 & 26 \\
6 & SDN Kebonsari 02 & 17 \\
\hline
\end{tabular}

Variabel pada penelitian ini meliputi variabel bebas dan variabel terikat. Variabel bebas dalam penelitian ini adalah Model Pembelajaran Mind Mapping berbantuan Media Display, sedangkan variabel terikat dari penelitian ini yaitu hasil belajar pada mata pelajaran Ilmu pengetahuan Sosial. Teknik pengumpulan data yang digunakan pada penelitian ini adalah tes, observasi, dokumentasi.

\section{HASIL DAN PEMBAHASAN}

Penelitian ini bertujuan untuk mengetahui model pembelajaran Mind Mapping berbantuan media display terhadap hasil belajar IPS siswa kelas IV. Hasil dari nilai pretest dan posttest merupakan sebuah dasar untuk melihat keefektifan model mind mapping berbantuan media display yang diukur dalam ranah kognitif peserta didik. Pretest yang diterapkan di kelas control dan ekperimen sebelum diterapkannya treatmen ini digunakan untuk mengetahui kesamaan pengetahuan awal peserta didik, sedangkan untuk menarik kesimpulan berdasarkan hipotesis penelitian peneliti menggunakan nilai posttest yang diberikan kepada

Tabel 2. Hasil Belajar Siswa

\begin{tabular}{cccccc}
\hline NO & KETERANGAN & \multicolumn{2}{c}{ PRETEST } & \multicolumn{2}{c}{ POSTTEST } \\
& & KNTRL EKSP & KNTRL & EKSP \\
\hline 1 & Jumlah siswa & 26 & 28 & 28 & 26 \\
2 & Rata-rata & 63,85 & 64,84 & 68 & 81 \\
3 & Nilai Terendah & 76 & 80 & 84 & 96 \\
4 & Nilai Terendah & 48 & 48 & 56 & 62 \\
5 & Jumlah siswa tuntas & 11 & 4 & 14 & 23 \\
\hline
\end{tabular}

Berdasarkan hasil pretest dan posttest yang telah disajikan dalam table maka dapat dilihat bahwa kemampuan awal peserta didik yang didapat dari pengambilan nilai pretest dari kedua kelas control dan eksperimen memiliki rata-rata yang sebanding, rata-rata nilai pretest pada kelas control ialah 63,85 sedangkan rata-rata pretest pada kelas ekperimen adalah 64,84 Akan tetapi hasil nilai posttest dari kedua kelas tersebut terlihat emiliki selisih, rata-rata nilai posttest pada kelas control yaitu 68 Sedangkan hasil nilai posttest kelas eksperimen adalah 81 . Terlihat terjadinya peningkatan yang cukup tinggi pada kelas ekperimen. Dengan hal ini maka dapat disimpulkan bahwa nilai posttest yang diperoleh kelompok kelas eksperimen yang menerapkan model mind mapping berbantuan media display lebih tinggi jika dibandingkan dengan kelas control yang menerapkan model Direct Intruction.

Setelah mendapatkan data seperti pada tabel 1.2 maka selanjutnya mencari hasil perhitungan uji normalitas data pretest pada kelas kontrol menggunakan uji Liliefors menggunakan Ms.Exel. kriteria pengujiannya adalah data dapat dikatakan data normal jika Lhitung < Ltabel (H0 diterima), sebaliknya jika data Lhitung $>$ Ltabel (H0 ditolak) data tidak berdistribusi normal. Berdasarkan data yang diperoleh data eksperimen dan control memiliki nilai lebih kecil dibandingkan dengan Ltebel yaitu $0.158<0.173$ maka dapat diambil kesimpulan $\mathrm{H} 0$ diterima dan data tersebut berdistribusi normal.

Berdasarkan hasil perhitungan uji homogenitas data nilai pretest SDN Sendangdawuhan 02 dan SDN Bulak 02 menggunakan uji $\mathrm{F}$ pada kelas eksperimen dengan kelas kontrol diperoleh Fhitung $=1.294766$ dan Ftabel 1.920974 maka H0 diterima karena Fhitung < Ftabel. Kesimpulan yang didaptkan berdasarkan hasil perhitungan uji homogenitas 
dapat diambil kesimpulkan bahwa H0 diterima sehingga data nilai pretest kelas eksperimen dan kelas kontrol memiliki varian yang sama atau homogen.

Perhitungan uji normalitas pada data posttest pada kelas kontrol menggunakan uji Liliefors menggunakan Ms.Excel dan bisa dikatakan normal apabila Lo $<\mathrm{L}$ tabel dan data posttest menunjukan $0.1304456<0.173$. Dengan demikian dapat disimpulkan bahwa $\mathrm{HO}$ diterima dan $\mathrm{Ha}$ ditolak, sehingga analisis data posttest pada kelas eksperimen dan kelas kontrol berdistribusi normal.

Berdasarkan hasil perhitungan uji homogenitas data nilai posttest menggunakan uji F pada kelas eksperimen dengan kelas kontrol diperoleh Fhitung $=1,0429$ dan Ftabel $=1,920974$ maka H0 diterima karena Fhitung $<$ Ftabel. Berdasarkan uji homogenitas dapat disimpulkan jika H0 diterima sehingga data nilai posttest kelas eksperimen dan kelas kontrol memiliki varian yang sama atau homogen.

Tabel 3. Uji Independen sample t-test t-test for equality of means

std.Error $95 \%$

\begin{tabular}{lcccc} 
& gig.(2-tailed Mean & \multicolumn{2}{c}{ Confidence lower } \\
\hline posttest EV & & & & 7.89 \\
Assumed & .000 & 13 & 2.5465 & 007 \\
EV not & & & & 7.88 \\
Assumed & .000 & 13 & 2.5486 & 859 \\
\hline
\end{tabular}

Hasil perhitungan menggunakan Independent Sample T-Test menujukan jika nilai (2tailed) $<0,05$,karena dalam tabel 4.6 diatas menunjukan bahwa kolom (2- tailed) yaitu sebesar 0,000 yang berarti lebih kecil dari 0.05 ,maka dapat dibaca jika terdapat perbedaan yang siginifikan antara hasil belajar kelas Eksperimen dan kelas kontrol. Dengan demikian dapat disimpulkan bahwa model pembelajaran mind mapping berbantuan Display lebih efektif dibandingkan model Direct Intruction terhadap hasil belajar IPS siswa kelas IV SDN Gugus KH.Samanhudi.

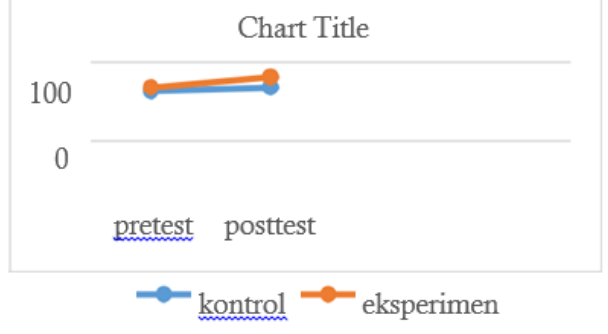

Gambar 2. Diagram Peningkatan Rata-rata Hasil Belajar IPS Siswa Kelas IV SDN Gugus KH.Samanhudi

Bersdasarkan gambar gambar 1.2 yang telah disajikan maka dapat dilihat bahwa kemampuan awal yang dimiliki peserta didik dalam kelas control dan kelas eksperimen hampir sama. Hal ini dibuktikan hasil perhitungan nilai pretest pada keldua kelas, yaitu kelas kontrol memiliki rata-rata 63.85 dan kelas ekperimen memiliki 64.84. Setelah diberi perlakuan berupa model pembelajaran mind mapping berbantuan media display, maka diperoleh hasil belajar IPS siswa kelas IV materi Keanekaragaman di Negeriku di kelas eksperimen lebih meningkat dibandingkan dengan kelas control ,dengan rincian pada kelas kontrol dan kelas ekperimen mempunyai selisih rata-rata nilai posttest yang cukup jauh. Sedangkan pada kelas kontrol mendapatkan skor posttest 68, dan kelas eksperimen mendapatkan rata-rata skor posttest 81 .

Tabel 4.Uji N-Gain

\begin{tabular}{ccc}
\hline kelas & N-Gain Score & Keteranga \\
\hline Kontrol & 0.12 & Tidak Efekt \\
Eksperimen & 0.49 & Sedang \\
\hline
\end{tabular}

Nilai n-gain yang didapat dari kelas eksperimen lebih tinggi jika dibandingkan nilai ngain di kelas kontrol. Nilai n-gain kelas kontrol yaitu 0,12 termasuk dalam kriteria tidak efektif, dan nilai n-gain kelas eksperimen adalah 0,49 termasuk dalam kriteria sedang. Berdasarkan hasil pretest dan posttest dengan berbagai perhitungan yang telah dilaksanakan tersebut menunjukkan peserta didik pada kelas eksperimen dengan penerapan model mind mapping berbantuan media display memiliki peningkatan hasil belajar dan lebih tinggi daripada siswa kelas kontrol yang menggunakan model Direct Intruction.

Hasil penelitian tersebut sejalan dengan hasil penelitian terdahulu yang pernah dilakukan oleh peneliti sebelumnya terkait dengan model pembelajaran mind mapping, diantaranya adalah penelitian eksperimen yang dilakukan oleh yang dilakukan oleh Ratih Shintia Devi, Margaretha Sri Yuliariatiningsih, dan Tita Mulyati (Vol. 3 No. 2 tahun 2015) Hasil penelitian memperlihatkan bahwa peningkatan pemahaman konsep IPA siswa yang memperoleh pembelajaran dengan metode Mind Mapping lebih baik daripada siswa yang memperoleh pembelajaran biasa.

Penelitian oleh Nur Astriany (2016:177) yang berjudul Meningkatkan Hasil Belajar IPA melalui Penggunaan Mind Map Siswa Kelas IV Sekolah Dasar Bekasi Utara dan Penelitian yang dikerakan oleh Zakariya Firasyan Syah, dkk (2014:422) dengan judul Penerapan Model Mind Map dalam Peningkatan Hasil Belajaran IPS Tema Sejarah Peradaban Indonesia pada Siswa Kelas V Di SD Negeri 1 Sruweng menunjukkan bahwa penggunaan model mind map dapat meningkatkan hasil belajar dan membuktikan adanya respon yang berbeda dari siswa dalam menangkap informasi yang disampaikan oleh guru. 
Perolehan tersebut didukung dengan penelitian yang telah dilakukan oleh D Hallen, dan N Sangeetha (2015:45) dengan penelitian ini menunjukkan jika berdasarkan uji-t diperoleh hasil ttabel $>$ thitung sehingga dapat diambil kesimpulan bahwa model pemetaan pikiran lebih efektif dibandingkan dengan metode konvensional. Penelitian yang dilakukan oleh Friezsya Puti Chandramica (54:2017), memberikan bukti bahwa penggunaan model pembelajaran mind mapping mempunyai pengaruh terhadap pembelajaran IPS materi keragaman budaya kelas IV SD 2 Gunung Terang Bandarlampung Tahun 2016/2017. Dibuktikan dengan uji dependent sample test pada taraf kepercayaan 5\% menunjukkan nilai t hitung sebesar 16,3 dengan probabilitas lebih kecil dari 0,05 yaitu 0,000 .

$$
\text { Penelitian Dyah.S, dan Darma.P }
$$

(595:2017) Siswa kelas V SDN Pacarkeling VI Surabaya menunjukan hasil yang meningkat dalam pembelajaran IPA dengan pokok materi siklus air dikarenakan peserta didik lebih paham memahami perjalanan siklus air tersebut. Hasil penelitian Ratih.S.D,dkk (1:2015) membuktikan jika terjadi peningkatan dengan pemahaman konsep IPA siswa yang memperoleh treatmen dengan metode Mind Mapping lebih baik daripada siswa yang memperoleh pembelajaran biasa. Hal ini ditunjukan dengan adanya perhitungan rata-rata gain yang menunjukan nilai sebesar 0,000 .

Penelitian Dyah.S,dan Darma.P (595:2017) Siswa kelas V SDN Pacarkeling VI Surabaya menunjukan hasil yang meningkat dalam pembelajaran IPA dengan pokok materi siklus air dikarenakan peserta didik lebih paham memahami perjalanan siklus air tersebut. Hasil penelitian Ratih.S.D,dkk (1:2015) membuktikan jika terjadi peningkatan dengan pemahaman konsep IPA siswa yang memperoleh treatmen dengan metode Mind Mapping lebih baik daripada siswa yang memperoleh pembelajaran biasa. Hal ini ditunjukan dengan adanya perhitungan rata-rata gain yang menunjukan nilai sebesar 0,000. Ida.Ayu,dkk (82:2018). Penelitian tentang komunikasi matematika menunjukan hasil yang dibuktikan dengan uji $t$ bahwa kemampuan komunikasi matematika siswa berkembang dengan baik menggunakan bantuan mind mapping dibandingkan dengan pembelajaran dengan model konvensional

Tara Satya HAdi (75:2019) data Hasil belajar siswa sebelum diterapkannya model Mind Mapping di kelas XI IPA 1 di SMA 1 Rowosari adalah 36,40 meningkat jadi 78,53. Penggunaan model Mind Mapping pada kelas XI di SMA Negeri 1 Rowosari sangat berpengaruh pada kelas eksperimen hal ini dapat dilihat dari hasil belajar siswa sebelum dan setelah menggunakan model Mind Mapping.

\section{SIMPULAN}

Kesimpulan dari penelitian yang dilakukan SD Negeri Gugus KH.Samanhudi Kabupaten Kendal, maka peneliti dapat menyimpulkan bahwa Model Mind Mapping efektif untuk meningkatkan hasil belajar siswa kels IV di Gugus KH.Samanhudi Kabupaten Kendal ini. Hasil penelitian menunjukan. Berdasarkan perhitungan tersebut menunjukan bahwa $\mathrm{H} 0$ ditolak dan $\mathrm{Ha}$ diterima, dan dapat ditarik kesimpulan jika model mind mapping berbantuan media display lebih efektif apabila dibandingkan dengan model direct instruction terhadap hasil belajar peserta didik dalam pelajaran IPS materi Keanekaragaman di Negeriku kelas IV SD N Gugus KH. Samanhudi Kabupaten Kendal.

Perbedaan hasil kognitif terlihat dari hasil pretest dan post test yang dilaksanakan sebelum dan sesudah pembelajaran (treatmen) pada kelas kontrol dan eksperimen. Berdasarkan hasil perhitungan pada kelas Eksperimen terlihat perkembangan yang cukup baik yaitu dari nilai rata-rata pretest 64,84 meningkat menjadi 81 . Sedangkan yang didapatkan dari kelas Kontrol ,rata-rata pretest 63,85 meningkat menjadi 68 .

Penerapan Model Mind Mapping berbantuan Media Display mengarah kearah positif dan terbukti lebih unggul dibandinngkan dengan model Pembelajaran langsung Direct Intruction jika diterapkan pada materi Keanekaragaman di Negeriku kelas IV.

\section{UCAPAN TERIMAKASIH}

Ucapan terimakasih disampaikan kepada Drs. Purnomo, M.Pd sebagai dosen pembimbing, Drs. Sukarjo, S.Pd.,M.Pd sebagai mitra bestari I, dan Dra. Arini Estiastuti,M.Pd.,sebagai mitra bestari II yang telah memberikan bimbingan dan masukan dalam penyusunan manuskrip.

\section{DAFTAR PUSTAKA}

Adodo, S O. 2013. Effect of Mind Mapping as a Self-Regulated Learning Strategy on Students' Achievement in Basic Science and Technology. Mediteranian Journal of Social Sciences. Vol. 4 No. 6

Astriany, Nur. 2016. Meningkatkan Hasil Belajar IPA melalui Penggunaan Mind Map Siswa Kelas IV Sekolah Dasar Bekasi Utara. Jurnal Pendidikan Dasar, 6(1):177.

Anggraeni, Yunita, dan Soeprajitno. 2014. Pengaruh Penerapan Metode Mind Mapping terhadap Hasil Belajar Siswa pada Mata Pelajaran IPS Materi Pokok Perjuangan Melawan Penjajah dan Pergerakan Nasional Indonesia 
Kelas V SDN Janti 1 WaruSidoarjo.Jurnal Pendidikan. Volume 01 Nomor 01.

Catur A. dkk. 2014. Pengaruh Model Pembelajaran Accelerated Learning Mind Mapping Terhadap Hasil Belajar Ipa Siswa Kelas V Sd No. 2 Tuban. Jurnal Mimbar PGSD Universitas Pendidikan Ganesha Jurusan PGSD

Devi, dkk. 2015. Efektivitas Metode Mind Mapping Terhadap Peningkatan Pemahaman Konsep Siswa pada Mata Pelajaran IPA. Jurnal Antologi UPI. Volume 3 Edisi No. 2

Gunawan dkk. 2016. Pengaruh Model Direct Instruction Berbantuan Simulasi Virtual Terhadap Penguasaan Konsep Siswa. Jurnal Pendidikan Fisika dan Teknologi (ISSN. 24076902)

Hallen, D dan Sangeetha, N. 2015. Effectiveness of Mind Mapping in English Teaching among VIII Standard Student. Imanagers's Journal on English Language Teaching. 5(1):45.

Liu Ying, dkk. 2014. The Effect of Mind Mapping on Teaching and Learning; A MetaAnalysis. Standard Journal of Education and Essay. Vol. 2 No. 1.

Nemati, Azadeh.dkk .2014. The Effect Of Mind Mapping Technique On The Enhancement Of Advanced Iranian Efl Learners' Essay Writing Ability Through Organizing Information And Thoughts. Indian Journal of Fundamental and Applied Life Sciences ISSN: 2231-6345

Nugraheny, Hesty dkk. 2019. Efektivitas Model Pembelajaran Campuran Auditory, Intellectually, Repetition, dan Group
Investigation dengan Model Pembelajaran Problem

Based Learning terhadap Kreativitas Berpikir. Unnes Physics Education Journal

Prahita, dkk. 2014. Pengaruh Penerapan Model Pembelajaran Mind Mapping terhadap Hasil Belajar IPA pada Siswa Kelas IV. e-Journal MIMBAR PGSD Universitas Pendidikan Ganesha Jurusan PGSD. Vol. 2 No. 1.

Rahayu C,Putu. 2018. Pengaruh Penggunaan Metode Mind Mapping Terhadap Hasil Belajar Ips Siswa Kelas V Sd Negeri 10 Metro Timur. Jurusan Ilmu Pendidikan Fakultas Keguruan dan Ilmu Pendidikan Universitas Lampung

Suherlin .dkk. 2017. Penerapan Model pembelajaran Mind Mapping Berbantuan Media Gambar Pada Mata Pelajaran IPS Terpadu Meningkatkan hasil Belajar Siswa Kelas Viii Smp Negeri 1 Darussalam. Jurnal Ilmiah Mahasiswa Pendidikan Geografi FKIP Unsyiah. Volume 2, Nomor 3, Hal 122-131

Natriani dan Ramlah. 2015. Penerapan Model Pembelajaran Mind Mapping Pada Mata Pelajaran Ilmu Pengetahuan Sosial Siswa Kelas IV SDN 54 Kota Pare Pare . Jurnal Publikasi Pendidikan VolumeVNo3

Widiari, dkk. 2014. Pengaruh Metode Pembelajaran Mind Mapping dan Ekspositori terhadap Hasil Belajar Matematika di SD Gugus IX Kecamatan Buleleng.e-Journal Edutech Universitas Pendidikan Ganesha 